\title{
The influence of actinomycin D on the protein composition of mouse uterine flushings
}

\author{
R. J. Aitken* \\ Department of Genetics, University of Edinburgh, U.K.
}

The termination of delayed implantation in the fur seal (Daniel, 1971, 1974), mouse (Aitken, 1977), rat (Surani, 1975) and roe deer (Aitken, 1974, 1975) is thought to be associated with the oestrogeninduced release of a protein-rich endometrial secretion into the uterine lumen. Finn (1974), however, observed that the intraperitoneal injection of actinomycin $\mathrm{D}$, an inhibitor of protein synthesis, terminated delayed implantation in the mouse within $48-72 \mathrm{~h}$. It was suggested that actinomycin $\mathrm{D}$ released the blastocysts from their state of diapause by inhibiting the transcription of a proteinaceous inhibitor of blastocyst attachment (Finn, 1974). Actinomycin D may, however, have increased the protein content of the uterine lumen either through the 'superinduction' of uterine proteins (Tomkins et al., 1969) or, possibly, through the stress-induced release of steroids from the adrenal glands. A study was therefore designed to determine the influence of actinomycin $\mathbf{D}$ on uterine secretory activity in the mouse.

The surgical and biochemical procedures used in this study were identical to those described by Aitken (1977). Uterine flushings were collected at 3, 6, 12, 24, 40, 48, 64 and $84 \mathrm{~h}$ after the intraperitoneal administration of $15 \mu \mathrm{g}$ actinomycin $\mathrm{D}$, and were analysed quantitatively and qualitatively for protein using the techniques of Lowry, Rosebrough, Farr \& Randall (1951) and Davis (1964) respectively. The presence of implantation sites was confirmed by observation of the uterus after an intravenous injection of pontamine blue $15 \mathrm{~min}$ before autopsy.

Discrete implantation sites were observed 48-64 h after the administration of actinomycin D, confirming the results obtained by Finn (1974). This implantation response differed in several ways from that obtained with oestradiol however. In a separate series of mice injected with $50 \mathrm{ng}$ oestradiol$17 \beta$ during diapause pontamine blue-positive areas were observed within $24 \mathrm{~h}$, at least $24 \mathrm{~h}$ earlier than in the actinomycin D-treated animals. The response to oestradiol was also more efficient in terms of both the number of animals possessing implantation sites (70\% and $100 \%)$ and the number

Table 1. Changes (mean \pm S.D.) in the protein content of mouse uterine flushings after administration of $15 \mu \mathrm{g}$ actinomycin $\mathrm{D}$ or $50 \mathrm{ng}$ oestradiol-17 $\beta$ during delayed implantation

\begin{tabular}{|c|c|c|c|c|}
\hline \multirow{2}{*}{$\begin{array}{l}\text { Time after } \\
\text { treatment } \\
\text { (h) }\end{array}$} & \multicolumn{2}{|c|}{ Oestradiol-17 $\beta^{*}$} & \multicolumn{2}{|c|}{ Actinomycin D } \\
\hline & $\begin{array}{c}\text { No. of mice } \\
(5 \mathrm{mice} / \mathrm{sample})\end{array}$ & $\begin{array}{l}\text { Conc. protein } \\
(\mu \mathrm{g} / \text { mouse })\end{array}$ & $\begin{array}{c}\text { No. of mice } \\
\text { ( } 5 \text { mice/sample) }\end{array}$ & $\begin{array}{c}\text { Conc. protein } \\
\text { ( } \mu \mathrm{g} / \text { mouse) }\end{array}$ \\
\hline 0 & 40 & $6.9 \pm 1 \cdot 2$ & 40 & $6 \cdot 9 \pm 1 \cdot 2$ \\
\hline 3 & 10 & $5 \cdot 3 \pm 0.2$ & 10 & $3.5 \pm 0.1$ \\
\hline 6 & 10 & $5.4 \pm 0.2$ & 5 & 3.6 \\
\hline 12 & 10 & $10 \cdot 9 \pm 1 \cdot 1$ & 10 & $3.0 \pm 0.1$ \\
\hline 24 & 5 & $4 \cdot 3$ & 10 & $3.7 \pm 1.5$ \\
\hline 40 & 10 & $10 \cdot 1 \pm 4 \cdot 3$ & 10 & $3 \cdot 4 \pm 1 \cdot 2$ \\
\hline 48 & 10 & $13 \cdot 3 \pm 7 \cdot 5$ & 10 & $2.7 \pm 0.3$ \\
\hline 64 & - & 二 & 10 & $4.9 \pm 0.1$ \\
\hline 84 & 一 & - & 10 & $3.8 \pm 1.3$ \\
\hline
\end{tabular}

* Data taken from Aitken (1977).

* Present address: M.R.C. Reproductive Biology Unit, 39 Chalmers Street, Edinburgh EH3 9ER, U.K. 

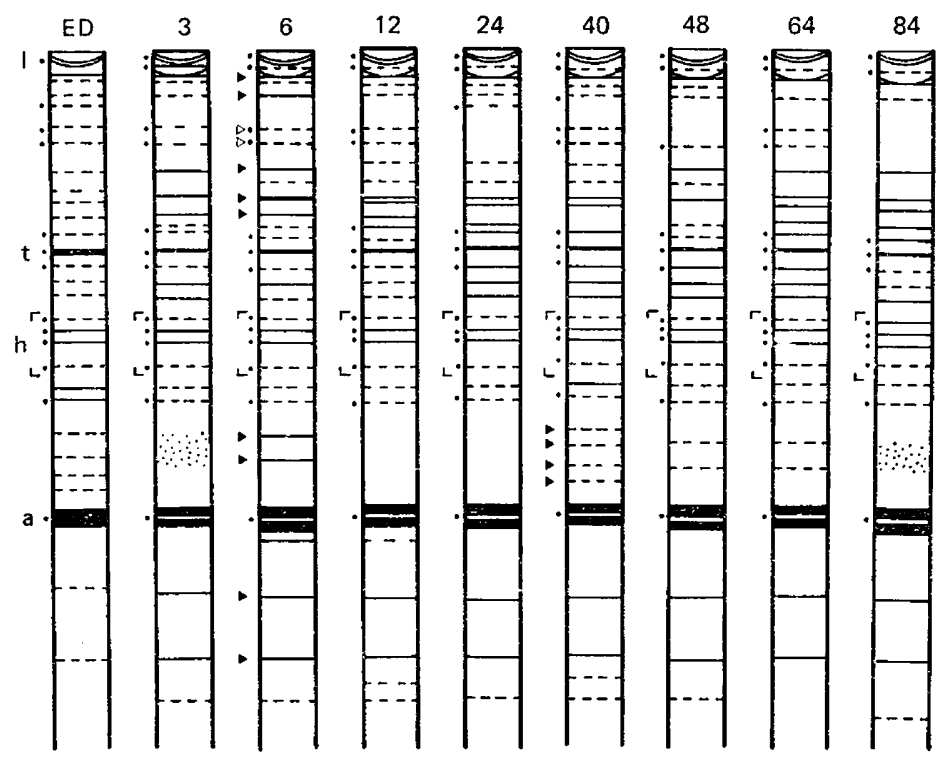

Text-fig. 1. Polyacrylamide gel electrophoresis of mouse uterine flushings after administration of $15 \mu \mathrm{g}$ actinomycin $\mathrm{D}$ during experimental delayed implantation. $\mathrm{ED}=$ Day 5 of experimental delay; 3, 6, 12, 24, $40,48,64$ and $84=\mathrm{h}$ after actinomycin $\mathrm{D}$ administration; at $6 \mathrm{~h}$, closed arrows $=$ major non-serum proteins at $R a 0.06,0.10,0.25,0.32,0.34,0.83,0.88,1 \cdot 19$ and 1.32 , open arrows = serum slow $\alpha$-globulins at $R a 0.16$ and 0.20 ; at $40 \mathrm{~h}$, closed arrows $=$ non-serum fast $\alpha$-globulins at $R a 0.83,0.86,0.90$ and $0.94 .1=$ major serum lipoprotein band; $t=$ serum transferrin; $h=$ haemoglobin bands; $a=$ albumin. Proteins identified by closed circles are presumed to be of serum origin.

of implantation sites per mouse (means of $4 \cdot 1$ and $11 \cdot 3$ ) for mice injected with actinomycin D and oestradiol respectively (see Table 1). These observations are in full agreement with those reported by Finn \& Downie (1975).

Considerable disparity was also observed in the uterine secretory response to actinomycin D and oestradiol. In contrast to the biphasic secretory response induced by oestradiol-17ß (Aitken, 1977), the induction of implantation with actinomycin $D$ was associated with a highly significant fall in the protein content of the uterine lumen $(P<0.001$; Table 1$)$. Despite this decline in total protein concentration, certain serum and non-serum proteins increased in intensity after actinomycin $D$ treatment (Text-fig. 1). The most significant changes were observed at $6 \mathrm{~h}$ when 2 serum and 9 non-serum proteins increased in intensity and a new band was observed at $R a 1 \cdot 06$, and at $40 \mathrm{~h}$ when a transient increase in 4 fast $\alpha$-globulins was detected. In untreated animals the protein pattern was found to remain substantially unchanged for up to 1 week after the induction of delayed implantation (Aitken, 1977).

The results obtained in this study indicate that the highly significant increase in luminal protein concentration observed at the time of implantation during normal pregnancy or following the administration of oestradiol-17ß (Aitken, 1977) is not an absolute requirement for the induction of blastocyst attachment: implantation was initiated when luminal protein levels were severely depressed by treatment with actinomycin $D$. It is possible that some of the minor qualitative changes observed following administration of actinomycin $\mathrm{D}$ were sufficient to activate the blastocysts, however, or that implantation depends on a change in the luminal epithelium rather than the luminal fluids (Pollard, Finn \& Martin, 1976).

I am very grateful to Dr Anne McLaren for her encouragement during this study and the M.R.C. for financial support in the form of a postdoctoral fellowship. 


\section{References}

AITKen, R.J. (1974) Delayed implantation in roe deer (Capreolus capreolus).J. Reprod. Fert. 39, 225-233.

AITKEN, R.J. (1975) Ultrastructure of the blastocyst and endometrium of the roe deer (Capreolus capreolus) during delayed implantation. $J$. Anat. 119, 369-384.

AITKEN, R.J. (1977) Changes in the protein content of mouse uterine flushings during normal pregnancy, delayed implantation, ovariectomy and oestradiol administration. J. Reprod. Fert. 50, 29-36.

DANIEL, J.C., JR (1971) Growth of the preimplantation embryo of the northern fur seal and its correlation with changes in uterine protein. Devl Biol. 26, 316322.

DANIEL, J.C., JR (1974) Circulating levels of oestradiol$17 \beta$ during early pregnancy in the Alaskan fur seal showing an oestrogen surge preceding implantation. J. Reprod. Fert. 37, 425-428.

DAvis, J.B. (1964) Disc electrophoresis. II. Method and application to human serum proteins. Ann. N.Y. Acad. Sci. 121, 404-427.
FINN, C.A. (1974) The induction of implantation in mice by actinomycin D. J. Endocr. 60, 199-200.

FinN, C.A. \& DownIE, J.M. (1975) Changes in the endometrium of mice after the induction of implantation by actinomycin D. J. Endocr. 65, 259-264.

Lowry, O.H., Rosebrough, N.J., FARR, A.L. \& RANDALL, R.J. (1951) Protein measurements with the Folin-phenol reagent. J. biol. Chem. 193, 265275.

Pollard, J.W., Finn, C.A. \& Martin, L. (1976) Actinomycin D and uterine epithelial protein synthesis. J. Endocr. 69, 161-162.

SURANI, M.A.H. (1975) Hormonal regulation of proteins in the uterine secretion of ovariectomized rats and the implications for implantation and embryonic diapause. J. Reprod. Fert. 43, 411-417.

TomkIns, G.M., Gelehrter, T.D., Granner, D., Martin, D., Samuels, H.H. \& Thompson, E.B. (1969) Control of specific gene expression in higher organisms. Science, N.Y. 166, 1474-1480.

Received 5 January 1977 